\title{
Characterisation of Biooxidation Feed and Products for Improved Understanding of Biooxidation and Gold Extraction Performance
}

\author{
Grace Ofori-Sarpong ${ }^{1, ~ *}$, Ahmed-Salim Adam ${ }^{1,2}$, Richard Komla Asamoah ${ }^{3}$, \\ Richard Kwasi Amankwah ${ }^{1}$ \\ ${ }^{1}$ Department of Minerals Engineering, University of Mines and Technology, Tarkwa, Ghana \\ ${ }^{2}$ Golden Star Prestea/Bogoso Resources, Bogoso Mine, Ghana \\ ${ }^{3}$ Future Industries Institute, University of South Australia, Mawson Lakes, Australia
}

Email address:

gofori-sarpong@umat.edu.gh (G. Ofori-Sarpong), aadam@gsrgh.com (A-S. Adam), Richmond.Asamoah@unisa.edu.au (R. K. Asamoah), rkamankwah@umat.edu.gh (R. K. Amankwah)

${ }^{*}$ Corresponding author

\section{To cite this article:}

Grace Ofori-Sarpong, Ahmed-Salim Adam, Richard Komla Asamoah, Richard Kwasi Amankwah. Characterisation of Biooxidation Feed and Products for Improved Understanding of Biooxidation and Gold Extraction Performance. International Journal of Mineral Processing and Extractive Metallurgy. Vol. 5, No. 2, 2020, pp. 20-29. doi: 10.11648/j.ijmpem.20200502.11

Received: March 13, 2020; Accepted: April 2, 2020; Published: May 15, 2020

\begin{abstract}
This paper presents a study on characterisation of refractory ore, biooxidation feed and product, and cyanidation tailings with the aim of understanding the causes of excessive continuous frothing, incomplete sulphide oxidation, high reagent consumption, high cyanidation residues and low overall recovery as encountered in biooxidation of refractory ores. Techniques involving carbon and sulphur speciation, Quantitative X-Ray Diffraction (QXRD), Scanning Electron Microscopy (SEM) and Optical Microscopy $(\mathrm{OM})$ were used to characterise the ore samples, flotation concentrate (BIOX® feed), biooxidised product (BIOX ${ }^{\circledR}$ CIL Feed) and cyanidation tailings (BIOX ${ }^{\circledR}$ CIL Tails) from a biooxidation plant. The main minerals present in the ore were quartz (45\%), chlorites (21\%), plagioclase feldspar (13\%), dolomite (5\%), pyrite $(2 \%)$ and mica group (2\%). The flotation concentrate recorded $18 \%$ mica, and this was responsible for excessive frothing in the biooxidation circuit as confirmed by the QXRD analysis. The carry-over froth to the CIL circuit led to short-circuiting of poorly leached material into the cyanidation tailings, resulting in high cyanidation residues. Secondary refractory minerals; gypsum and jarosite, which were observed in the biooxidation product by the QXRD, have the potential to coat unreacted sulphide particles, leading to incomplete sulphide oxidation as observed here. Partially oxidised sulphides led to high consumption of reagents such as oxygen and cyanide during cyanidation. Gypsum and jarosite also encapsulated gold particles as observed in the BSED analysis. Coated gold particles had reduced access to lixiviants during the subsequent cyanidation process, leading to high leach residues. The biooxidised product (BIOX® CIL Feed) also recorded a high organic carbon content of 6.67 , while analysis by BSED revealed the presence of graphitic carbon and coatings on gold surfaces; an indicator for high preg-robbing activities during cyanidation of the concentrate. Preg-robbing indices of $64.4 \%$ and $72.7 \%$ were recorded for the flotation concentrate (BIOX® feed) and BIOX $^{\circledR}$ CIL feed respectively. The overarching effect of all the observations is a decrease in overall gold recovery.
\end{abstract}

Keywords: Biooxidation, Refractory Gold Ore, Cyanidation, Secondary Refractory Minerals, Preg-Robbing Ores, Frothing

\section{Introduction}

The application of biooxidation in the processing of refractory gold ores has gained acceptance over alternatives such as roasting and pressure oxidation because it is robust, has less laborious operational and environmental requirements, and uses a consortium of non-pathogenic microbes that are harmless to organic life [1]. Comparative tests have demonstrated that bioleaching can achieve the same or better results than roasting or pressure leaching in terms of gold recovery and cost-effectiveness [2-7]. Biooxidation makes use of chemolithotrophic microbes such as Acidithiobacillus thiooxidans, Acidithiobacillus ferrooxidans, 
Leptospirillum ferrooxidans, Acidithiobacillus caldus, Leptospirillum ferriphilum, Sulfobacillus thermosulfidooxidans, and Sulfobacillus benefaciens to catalyse the oxidation of sulphide minerals [5, 8-9]. The microbes derive their energy from the oxidation of sulphur and iron, transforming the sulphide matrix into oxide matter and liberating gold particles for subsequent leaching. Carbonaceous materials are, however, not oxidised or deactivated by this pre-treatment step and continue to preg-rob in subsequent gold leaching process [10-13]. Commercial BIOX $^{\circledR}$ plants around the world operate at above $90 \%$ leach recoveries from a concentrate obtained from less than $3 \mathrm{~g} / \mathrm{t}$ refractory ore grade. However, high leach residues in the range of 2-16 g/t result in generally low overall recoveries in the range of 70-80\% [14-15], and this presents a great challenge in running such plants.

The major control variables in the operation of a bacterial oxidation plant are the $\mathrm{Fe}^{3+}: \mathrm{Fe}^{2+}$ ratio, redox potential, $\mathrm{pH}$ and sulphide sulphur oxidation [5]. Though these variables may be controlled well, certain ore characteristics may still make the operations challenging. This paper presents a study on characterisation of the ore, biooxidation feed and product, and cyanidation tailings with the aim of understanding the basis for excessive continuous frothing, incomplete sulphide oxidation, high reagent consumption, high cyanidation residues and low overall recovery as experienced by such processing plants.

\section{Experimental Investigations}

\subsection{Materials}

Ore and concentrate samples for the investigation were collected from the sulphide treatment plant of a mine in Ghana The specific samples collected were $30 \mathrm{~kg}$ each of; mill feed ore samples crushed to $-150 \mathrm{~mm}$, flotation concentrate milled to $-45 \mu \mathrm{m}$ (FC), biologically oxidised flotation concentrate (BIOX $^{\circledR}$ CIL feed), and tailings from the post BIOX ${ }^{\circledR}$ Carbon in Leach circuit (BIOX ${ }^{\circledR}$ CIL tails). In each case, the samples were collected and composited over a two-week period, homogenised and split for the various tests.

\subsection{Methods}

\subsubsection{Chemical and Mineralogical Characterisation of Samples}

The relative amounts of various mineral phases and elements were determined using Quantitative X-Ray Diffraction (QXRD) and Scanning Electron Microscopy (SEM), coupled with selected sample overview by Optical Microscopy (OMS). Complete bulk elemental analysis was conducted by X-ray Florescence (XRF) and Energy-dispersive X-ray Spectroscopy (EDX) to augment the results of the partial chemical analysis. All samples for these investigations were prepared by homogenising using a vibrating mixer, and sub-samples were taken using a Macro riffle splitter and rotary micro-riffler. Dry de-agglomeration of samples was done on glossy paper using a rolling pin to ensure that particles were not clumped.

XRD was done using a PANalytical X'Pert Pro PW3040 diffractometer equipped with X'Pert HighScore Plus search/match software for mineral identification. To quantify the minerals, Rietweld quantitative analysis was performed on the XRD patterns using commercial package, SIROQUANT ${ }^{\mathrm{TM}}$ V3 from Sietronics Pty Ltd. OMS and SEM sample blocks of diameter $30 \mathrm{~mm}$ were prepared with EpoFix resin and hardener, and grinding/polishing was done using TegraPol and TegraForce units. The SEM samples were further coated with graphite and mounted onto double side sticky tape [16-18]. SEM analysis was carried out using Camscan Model CS44FE scanning electron microscope at an acceleration voltage of 20 $\mathrm{kV}$ and $30 \mathrm{kV}$, unless otherwise stated.

\subsubsection{Relative Preg-robbing Index}

Relative preg-robbing index of the flotation concentrate and BIOX $^{\circledR}$ CIL feed were evaluated. The approach was by comparing the direct cyanide leach performance without activated carbon (AC) with leaching in the presence of activated carbon. The difference in performance indicates the relative preg-robbing index. The preg-robbing factor is calculated as shown in Equation 1.

$$
P R I=\left[\frac{\text { Recovery with } A C-\text { Recovery without } A C}{\text { Recovery with carbon }}\right] \times 100 \%
$$

\subsubsection{Diagnostic Leach}

Diagnostic leach test was conducted on the flotation concentrate, $\mathrm{BIOX}^{\circledR} \mathrm{CIL}$ feed and $\mathrm{BIOX}^{\circledR}$ CIL tailings to establish the gold deportment in the samples. This process, having several versions for process plant design and troubleshooting, allows the gold associated with different groups of mineral phases such as oxides, carbonates, sulphides, and carbonaceous matter to be determined [19-20]. The procedure used in this study is detailed in Figure 1. The first step involved cyanidation of $1 \mathrm{~kg}$ sample at $40 \%$ solids, $0.5 \mathrm{~kg} / \mathrm{t}$ cyanide and $\mathrm{pH} 10.5$ for $24 \mathrm{~h}$. The residue was water-washed and digested sequentially with $5 \% \mathrm{HCl}, 1: 1$ of $\mathrm{HNO}_{3}: \mathrm{H}_{2} \mathrm{O}$ until effervescence ends and each digestion step was followed by cyanidation. The tailings from cyanidation after digestion with $\mathrm{HNO}_{3}$ was roasted at $750^{\circ} \mathrm{C}$ for $4 \mathrm{~h}$ and leached with cyanide, while the final tailings material was subjected to fire assay.

The first cyanidation leach results indicate free-milling gold. To quantify the gold that was preg-robbed, but recoverable by CIL processing, a parallel sample was leached in the presence of activated carbon. The post $\mathrm{HCl}$ digest cyanidation leach shows gold in carbonates. The nitric acid leach releases gold associated with sulphides while gold from the roasting calcine is indicative of gold in carbonaceous matter. The tailings from the calcine leach represents gold in refractory silicates. At the end of each cyanide-leaching period, the pulp was filtered, and the solution obtained was analysed for gold by 240FS AA Atomic Absorption Spectrophotometer, whereas the residual solids (tailings) were assayed for residual gold by fire assaying followed by AAS finish. All the tests were done in duplicates, and the results presented are the average values. 


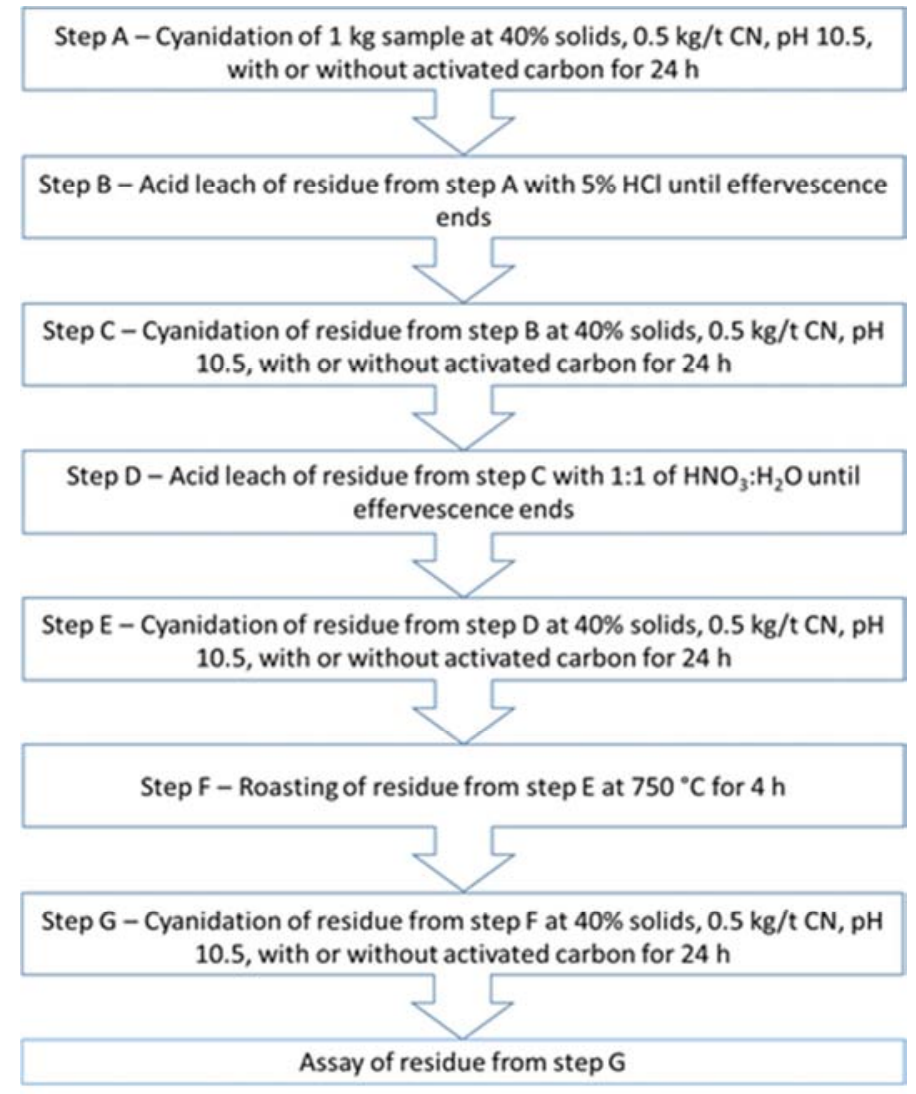

Figure 1. Diagnostic leaching route [14].

\section{Results and Discussions}

\subsection{Chemical Analyses}

The chemical analysis results of the four streams; run-of-mine ore feed, flotation concentrate $\left(\mathrm{BIOX}^{\circledR}\right.$ feed), BIOX $^{\circledR}$ CIL feed and BIOX $^{\circledR}$ CIL tailings are presented in Tables 1 and 2. Table 1 shows the gold grades, carbon and sulphur speciation with sulphur concentration in excess of $1 \%$ [5], confirming the ore as sulphidic. The $0.13 \%$ difference in sulphide sulphur and total sulphur indicates possible presence of sulphates from natural oxidation of sulphide minerals. From an initial concentration of $1.07 \%$, the sulphide sulphur content increased to $8.22 \%$ after flotation, showing an enrichment ratio of 7.7.

Biooxidation reduced the sulphide sulphur content to $0.42 \%$, recording an efficiency of $95 \%$. Despite the low sulphide sulphur content, the total sulphur was high at $2.58 \%$, an occurrence which may be attributed to other sulphur species such as elemental sulphur and sulphates, among others. Such sulphur species, especially those that are partially oxidised, have the capacity to consume significant amounts of leaching reagents like cyanide, oxygen and lime [12-13, 17, 21]. The high organic carbon content recorded in the BIOX product was an indicator for high preg-robbing activities during cyanidation of the concentrate.

Table 1. Results of partial chemical analysis.

\begin{tabular}{|c|c|c|c|c|c|c|}
\hline \multirow{2}{*}{ Sample } & Au & $\overline{S_{\text {total }}}$ & $\mathrm{S}^{2-}$ & $\operatorname{Org} C$ & $\mathrm{C}_{\text {total }}$ & $\mathrm{CO}_{3}{ }^{2-}$ \\
\hline & $g / t$ & $\%$ & $\%$ & $\%$ & $\%$ & $\%$ \\
\hline Run-of-mine ore & 2.29 & 1.20 & 1.07 & 1.08 & 11.25 & 10.5 \\
\hline Flot conc $(\mathrm{BIOX} \AA$ feed $)$ & 17.39 & 9.56 & 8.22 & 3.21 & 5.05 & 9.02 \\
\hline BIOX® CIL feed & 34.60 & 2.58 & 0.42 & 6.67 & 7.13 & 3.78 \\
\hline BIOX $®$ CIL tails & 3.69 & 3.36 & 0.86 & 4.84 & 5.75 & 4.55 \\
\hline
\end{tabular}

The ratios of $\mathrm{Au}: \mathrm{S}^{2-}$ and $\mathrm{S}^{2-}: \mathrm{CO}_{3}{ }^{2-}$ are critical factors to the amenability of an ore to BIOX ${ }^{\circledR}$ treatment. Au: $\mathrm{S}^{2-}$ of $>0.7$ : 1 renders a $\mathrm{BIOX}^{\mathbb{R}}$ project viable with low downstream operating costs [3]. Thus, the flotation concentrate having a ratio of 2.1 in the present study met the requirement. The presence of carbonates has the potential to render the biooxidation reaction net acid-consuming due to the titration of carbonate by sulphuric acid. In such situations, sulphuric acid may be pumped into the circuit increasing production cost in the process. In this work, a $\mathrm{S}^{2-}: \mathrm{CO}_{3}{ }^{2-}$ ratio of 0.9 was observed, giving indication of high acid consumption. Starting from a BIOX ${ }^{\circledR}$ CIL feed of grade, $34.6 \mathrm{~g} / \mathrm{t}$, gold recovery after cyanidation was $89.3 \%$ leaving a tailings grade of $3.69 \mathrm{~g} / \mathrm{t}$. Studies show that operators of BIOX plants have tailings grades in the range of 2-16 g/t from concentrate grades in the range of $30-160 \mathrm{~g} / \mathrm{t}$ [15]. The concentrations of other elements as determined by X-ray 
Florescence (XRF) are presented in Table 2.

Table 2 shows high potassium, which should be considered when introducing nutrients for bioxidation. Smart control of nutrient dose will be very useful to prevent formation of excessive refractory secondary sulphate minerals such as jarosite. The low arsenic content $(0.03 \%)$ indicates that the arsenopyrite concentration in the ore was relatively low. The sulphur results obtained by XRF agree with those obtained by the combustion volumetric technique in Table 1, and the data also shows that bacterial oxidation is capable of reducing the concentrations of $\mathrm{Fe}, \mathrm{S}$ and As.

Table 2. XRF/Laser Ablation-MS results for run-of-mine ore flotation concentrate and BIOX ${ }^{\circledR}$ CIL feed.

\begin{tabular}{|c|c|c|c|}
\hline \multirow[b]{2}{*}{ Sample } & \multicolumn{3}{|l|}{ Percent (\%) } \\
\hline & Run of Mine Ore & $\begin{array}{l}\text { Flotation } \\
\text { Concentrate }\end{array}$ & BIOX $^{\circledR}$ CIL feed \\
\hline $\mathrm{Al}$ & 7.54 & 6.89 & 8.77 \\
\hline As & 0.03 & 2.01 & 0.20 \\
\hline $\mathrm{Ba}$ & 0.03 & 0.05 & 0.06 \\
\hline $\mathrm{Ca}$ & 1.16 & 0.91 & 0.97 \\
\hline $\mathrm{Cl}$ & 0.00 & 0.01 & 0.01 \\
\hline $\mathrm{Co}$ & 0.01 & 0.01 & 0.00 \\
\hline $\mathrm{Cr}$ & 0.01 & 0.01 & 0.02 \\
\hline $\mathrm{Cu}$ & 0.01 & 0.07 & 0.03 \\
\hline $\mathrm{Fe}$ & 10.00 & 12.84 & 3.61 \\
\hline K & 0.83 & 1.58 & 2.05 \\
\hline $\mathrm{Mg}$ & 2.58 & 0.81 & 0.32 \\
\hline $\mathrm{Mn}$ & 0.17 & 0.05 & 0.00 \\
\hline $\mathrm{Na}$ & 0.81 & 0.89 & 1.11 \\
\hline $\mathrm{Ni}$ & 0.01 & 0.03 & 0.00 \\
\hline $\mathrm{P}$ & 0.07 & 0.06 & 0.06 \\
\hline $\mathrm{Pb}$ & 0.01 & 0.00 & 0.00 \\
\hline S & 1.03 & 10.10 & 2.31 \\
\hline $\mathrm{Si}$ & 24.66 & 19.31 & 24.64 \\
\hline $\mathrm{Sn}$ & 0.00 & 0.00 & 0.00 \\
\hline $\mathrm{Sr}$ & 0.02 & 0.01 & 0.02 \\
\hline $\mathrm{Ti}$ & 0.66 & 0.59 & 0.87 \\
\hline V & 0.03 & 0.01 & 0.02 \\
\hline $\mathrm{Zn}$ & 0.02 & 0.03 & 0.01 \\
\hline $\mathrm{Zr}$ & 0.01 & 0.03 & 0.02 \\
\hline LOI* & 7.30 & 17.06 & 15.45 \\
\hline
\end{tabular}

*Loss of Ignition.

\subsection{Relative Preg-robbing Index (PRI)}

Due to the high amounts of organic carbon observed in the flotation concentrate and the BIOX $^{\circledR}$ CIL Feed, it was necessary to determine the Preg-robbing Index (PRI) of the samples as presented in Figure 2. From Figure 2, it can be seen that both samples of pre- and post-BIOX concentrates were highly preg-robbing [12-13, 22-24], and the flotation concentrate to $\mathrm{BIOX}^{\mathbb{R}}$ treatment rather increased the PRI from $64.4 \%$ to $72.7 \%$, confirming that the BIOX process does not degrade carbonaceous matter in double-refractory ores [10-12, $14,25]$.

Work done by [12] on preg-robbing of gold from cyanide and non-cyanide complexes reported a higher percentage of preg-robbing by $\mathrm{BIOX}^{\circledR}$ product than $\mathrm{BIOX}^{\circledR}$ feed, and attributed it to the higher percentages of organic carbonaceous matter even after biooxidation. The increase in organic carbon grades in the BIOX $^{\circledR}$ CIL feed may be due to carry-over of dead bacterial cells attached to ore particles and acting as carbonaceous matter and/or as a result of dissolution of sulphur leading to relative increase in the percentage of organic carbon and total carbon as evident in Table 1.

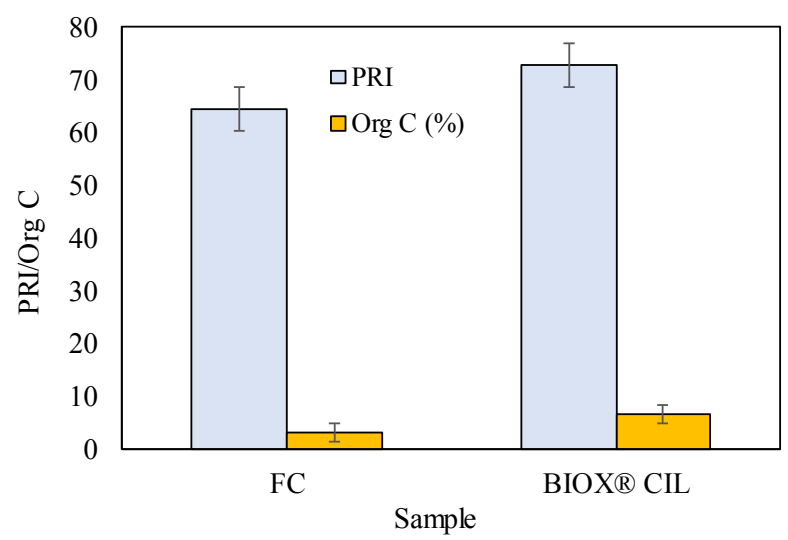

Figure 2. Preg-robbing index and organic carbon content of flotation concentrate (FC) and biooxidised product (BIOX ${ }^{\circledR}$ CIL feed).

\subsection{Quantitative X-ray Diffraction Analyses}

Quantitative X-ray Diffraction (QXRD) results identified the predominant minerals among all four samples to be silicates, oxides, carbonates and sulphides. The QXRD results of ROM, FC and BIOX ${ }^{\circledR}$ CIL feed are consistent with those reported by reference [16] on similar samples in a collaborative research. Quantitative distribution of the various mineral phases is shown in Figure 3 while the diffraction pattern is presented in Figure 4. The flotation feed (ROM) ore contained $45 \%$ quartz, $21 \%$ chlorites, $13 \%$ plagioclase feldspar, $5 \%$ dolomite, $2 \%$ pyrite and $2 \%$ mica.

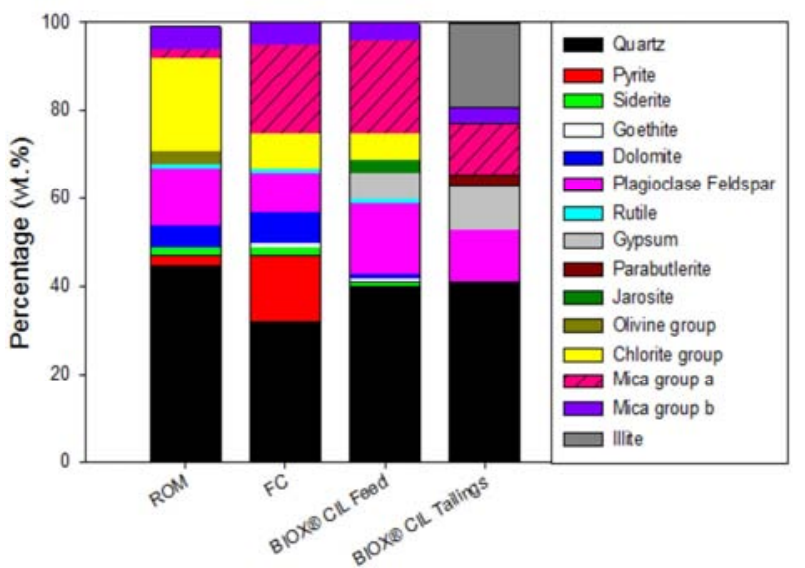

Figure 3. $Q X R D$ result showing the relative abundance of identified minerals in the four sample streams.

The presence of the gangue minerals such as mica generally pose recovery challenges in flotation. The mica group and other naturally hydrophobic minerals will readily float in the flotation circuit causing dilution of concentrate, and these will impact on downstream recovery processes. The flotation process led to an upgrade of $13 \%$ pyrite and $18 \%$ mica with respect to the initial ROM sample results. The 8 -fold increase 
in mica will cause frothing and hence recovery challenges in the BIOX $^{\circledR}$ process. The content of quartz, plagioclase

feldspar and chlorite group, however, reduced.

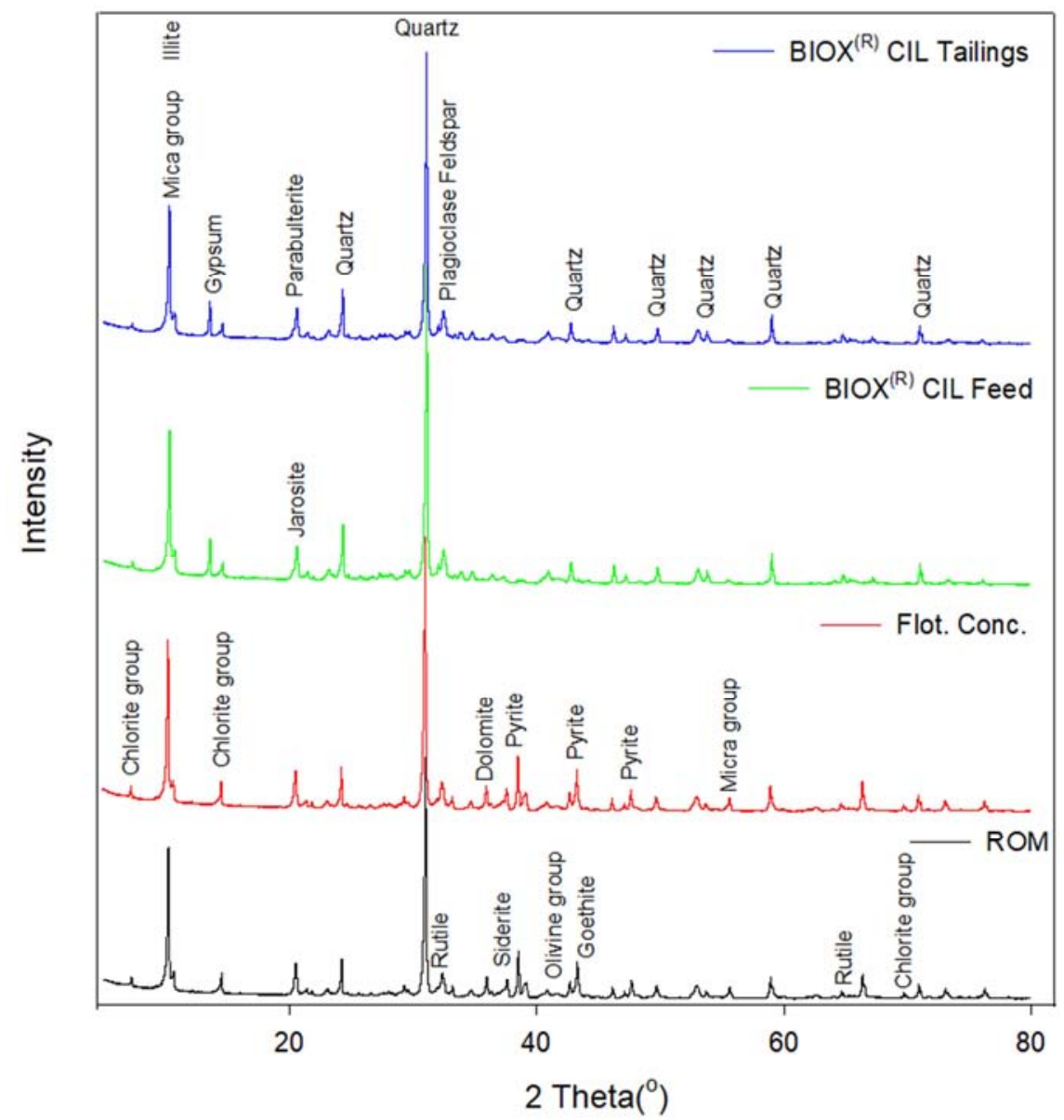

Figure 4. X-ray diffraction patterns of run-of-mine (ROM), flotation concentrate (FC), biooxidised product (BIOX ${ }^{\circledR}$ CIL feed), and cyanidation tailings (BIOX ${ }^{\circledR}$ CIL Tails).

The oxidative action of the $\mathrm{BIOX}^{\circledR}$ process on pyrite and the acid attack on the carbonates and phyllosilicate minerals resulted in low levels $(<1 \%)$ of pyrite, dolomite and siderite minerals in the BIOX ${ }^{\circledR}$ CIL feed. Mica group remained about the same, and this will cause problems as mica has proven to be the most recalcitrant component of concentrate in the BIOX $^{\circledR}$ process $[5,26]$.

Another characteristic of interest in the $\mathrm{BIOX}^{\circledR}$ product is the formation of jarosite and gypsum. In the biooxidation process, potassium is supplied as nutritional supplement. Excessive supply of potassium, however, has the tendency to make high concentration of $\mathrm{K}^{+}$available in a high $\mathrm{Fe}^{3+}$ medium for an enhanced formation of jarosite $\left(\mathrm{KFe}_{3}(\mathrm{OH})_{6}\left(\mathrm{SO}_{4}\right)_{2}\right)$. With the levels of potassium recorded in Table 2 and the addition of more nutrients for BIOX $^{\circledR}$, there will exist excess potassium for jarosite formation [27-28]. The formation of jarosite will result in depletion of available $\mathrm{K}^{+}$ from the solution and cause coating of the sulphide minerals and liberated gold particles. Though the kinetics of ferric iron precipitation to form jarosite is relatively slow at the operating temperatures of BIOX, studies continue to record the presence of jarosite [26, 29-33]. This is attributed to the longer residence time and occasional increase in reactor $\mathrm{pH}$ close to 2.0 in BIOX operations.

Gypsum $\left(\mathrm{CaSO}_{4} \cdot 2 \mathrm{H}_{2} \mathrm{O}\right)$ on the other hand is formed due to the addition of lime in the $\mathrm{BIOX}^{\circledR}$ circuit to adjust the $\mathrm{pH}[31$, 33]. This occurs when the $\mathrm{BIOX}^{\circledR}$ reaction leads to higher acidity than is required by the bacteria. Gypsum can also be formed in the preconditioning stage prior to the CIL leach where the $\mathrm{pH}$ of biologically oxidized concentrate is adjusted from $\mathrm{pH} 2.5$ to 10.5. Inefficient washing prior to preconditioning will result in the formation of more gypsum due to the presence of more sulphates, and this will lead to coating of liberated gold particles.

Analyses of the leach residue (BIOX ${ }^{\circledR}$ CIL Tails) revealed high levels of quartz (41\%), plagioclase feldspar $(12 \%)$, gypsum (10\%) and a combined $15.4 \%$ mica group of minerals. Illite recorded $19 \%$ though it was absent in the ROM, FC and BIOX $^{\circledR}$ CIL feed samples. Minor amounts of the sulphate mineral, parabutlerite $\left(\mathrm{Fe}^{3+}\left(\mathrm{SO}_{4}\right)(\mathrm{OH}) \cdot 2 \mathrm{H}_{2} \mathrm{O}\right)$ were also detected.

\subsection{Optical and Scanning Electron Microscopy Studies}

The optical microscopy (OMS) results as shown in Figure 5 
agree with the QXRD data. Pyrite existed mainly as cubic euhedral to sub-euhedral coupled with a lot of quartz and few
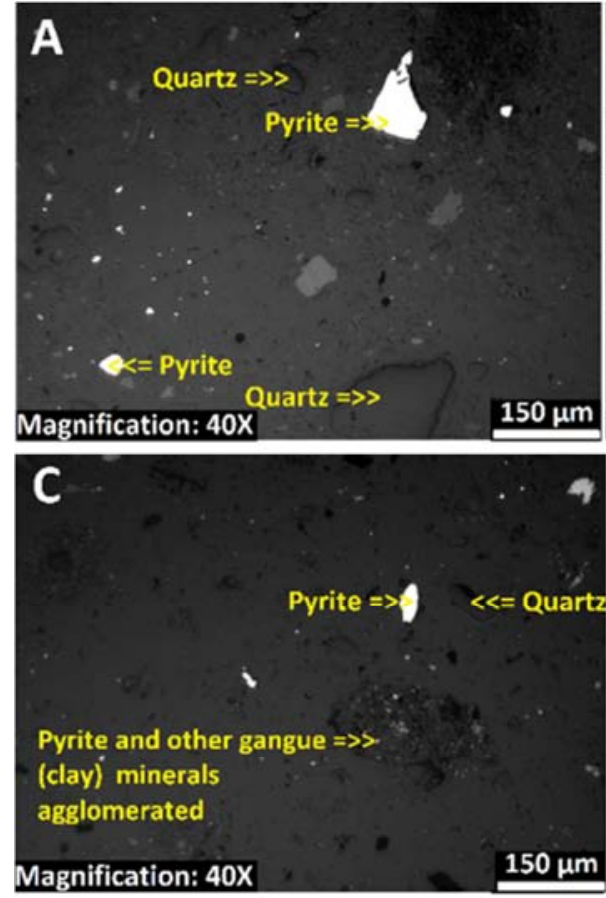

Figure 5. Photomicrographs of samples: (A) run-of-mine ore (B) flotation concentrate, (C) BIOX ${ }^{\circledR}$ CIL feed and (D) BIOX $X^{\circledR}$ CIL Tails.

The flotation concentrate sample (B) had high pyrite concentration due to the upgrading that occur in flotation, while the $\mathrm{BIOX}^{\mathbb{B}}$ CIL feed (C) showed a major reduction in the amount of pyrite present due to the oxidative action in the BIOX $^{\circledR}$ process $(95 \%$ sulphide oxidation). The very large pyrite minerals were reduced to smaller sizes. A higher magnification view of the $\mathrm{BIOX}^{\circledR}$ CIL tails (D) revealed the presence of residual pyrite that was not noticeable by QXRD. Other silica-based minerals were seen in agreement with the QXRD results.

SEM study of BIOX ${ }^{\circledR}$ CIL feed generally showed particles of varied shapes. Further analysis of images captured by
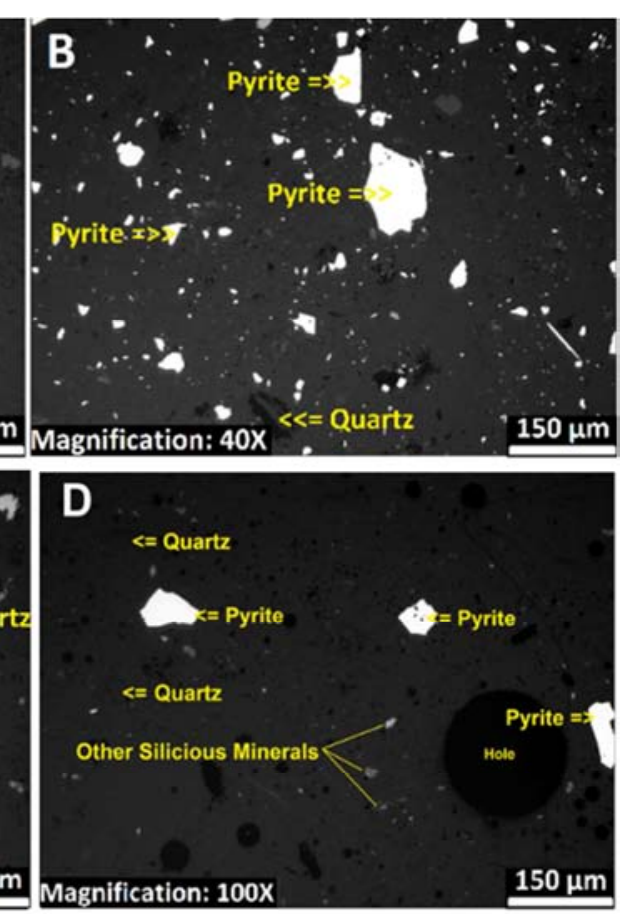

pyrite minerals in the ROM ore (A).

backscattered electron detector (BSED) of the BIOX ${ }^{\circledR}$ CIL feed (Figure 6) revealed other minerals such as monazite $(\mathrm{Ce})$, arsenopyrite, magnesium oxide, chalcopyrite and muscovite (with $\mathrm{Mg}, \mathrm{Na}, \mathrm{Kr}$, and $\mathrm{Fe}$ impurities) that were not identified by the OMS and QXRD [16]. Very fine free Au particles were also observed and inferred to have been liberated by the oxidative action of the bacteria [5].

A closer observation of a gold particle in the BIOX $^{\circledR}$ CIL feed is shown in Figure 7, where EDX spectra on the gold particles are shown alongside the SEM (A) and BSED (B) images.
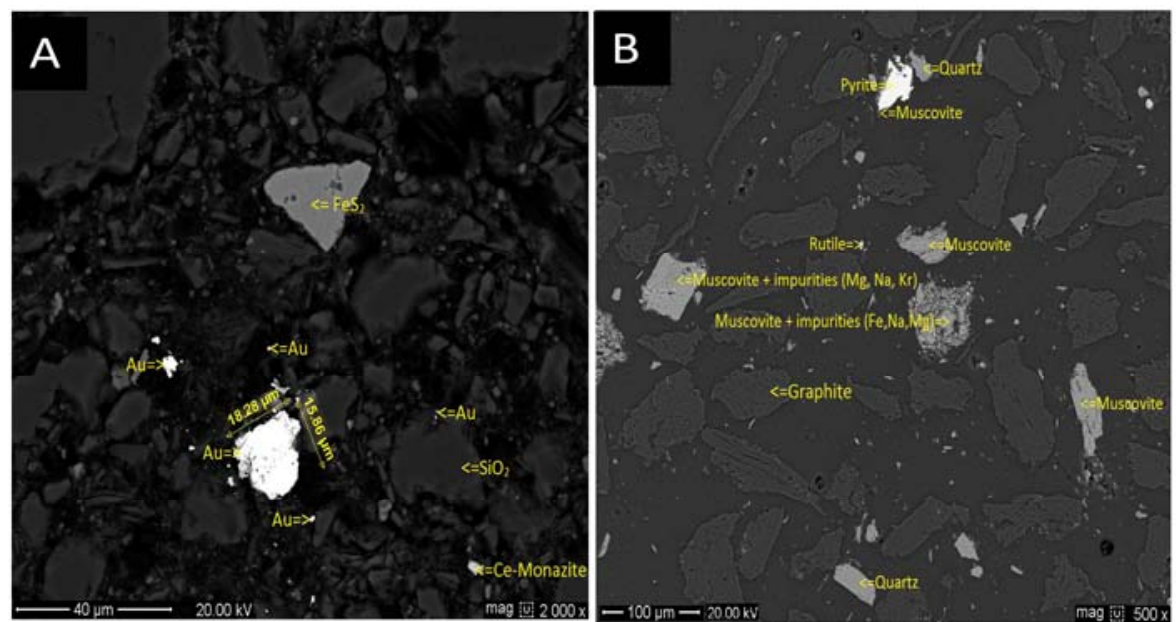

Figure 6. BSED results of $\mathrm{BIOX}^{\circledR \mathrm{C}} \mathrm{CIL}$ feed showing: (A) Au, Monazite (Ce), $\mathrm{SiO}_{2}$, and $\mathrm{FeS}_{2}$; (B) Muscovite (with $\mathrm{Mg}$, Na, Fe and $\mathrm{K}$ impurities), Graphite, SiO ${ }_{2}$, $\mathrm{FeS}_{2}$ and $\mathrm{TiO}_{2}$. 


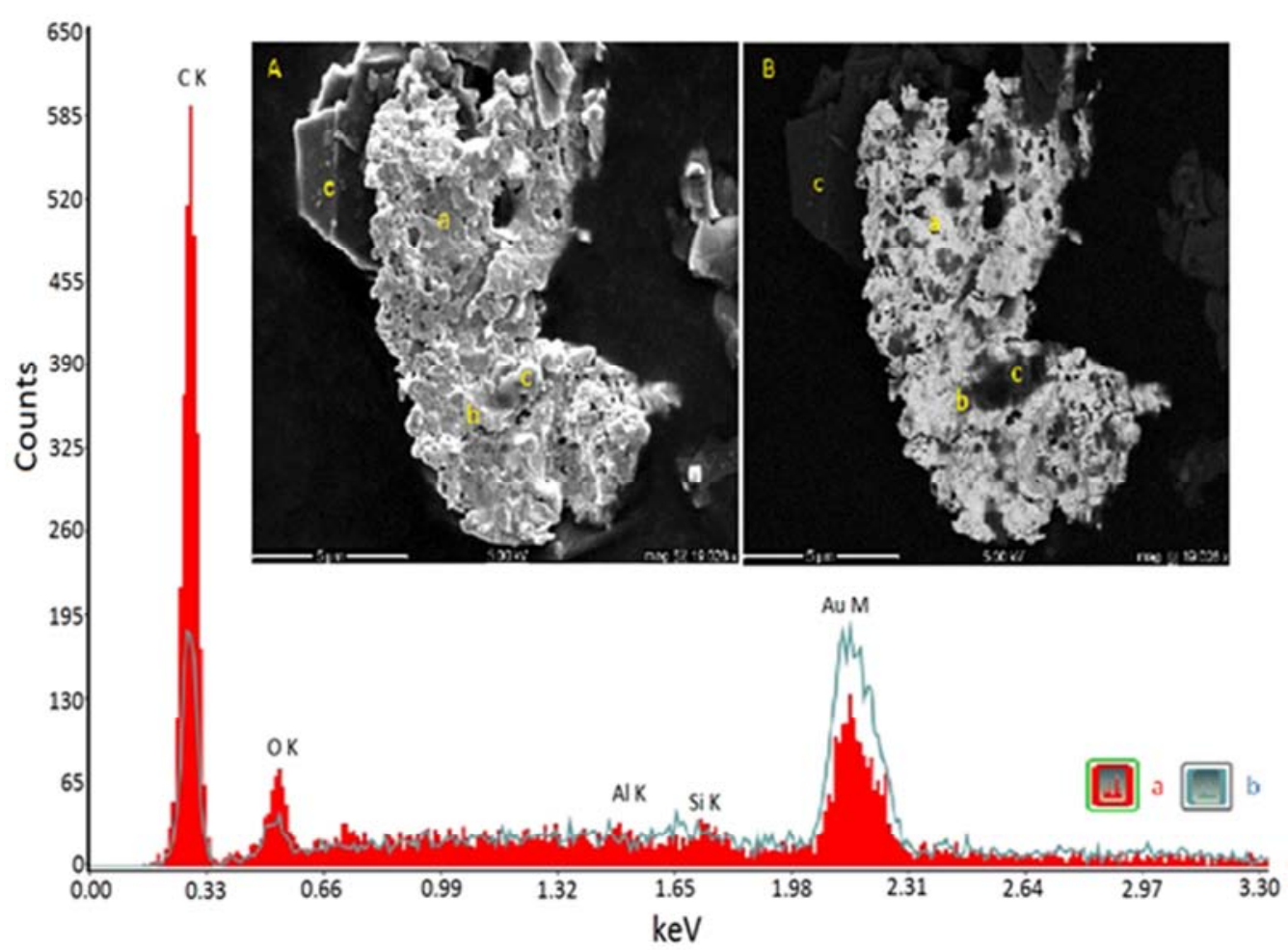

Figure 7. Micrograph and EDX spectra of Gold in BIOX ${ }^{\circledR}$ CIL Feed showing SEM (A) and BSED (B) images; with a, b, and $c$ showing Au, organic carbon and alumino-silicate, respectively.

Gold (a) was observed in association with organic carbon (b) and alumino-silicates (c). The gold surface was smeared with organic carbon which would affect gold dissolution and adsorption. This effect was demonstrated by [34] when carbonaceous matter was ground with non-carbonaceous ores, resulting in significant decrease in gold leaching kinetics and recoveries.

\subsection{Diagnostic Leaching}

The results of gold deportment in various mineral components in the flotation concentrate and the $\mathrm{BIOX}^{\circledR} \mathrm{CIL}$ tailings as obtained from the diagnostic leach test are depicted in Figure 8. The idea was to ascertain the gold inclusions before the $\mathrm{BIOX}^{\circledR}$ pretreatment step and to interrogate the gold associations in the CIL leach residue and shed light on the causes of high tailings grade. The flotation concentrate showed a gold deportment of $9 \%$ in the free-milling component, while $10 \%, 43 \%, 32 \%$ and $6 \%$ of the gold were in association with carbonates, sulphides, carbonaceous matter and quartz respectively. These results confirm the double-refractory nature of the concentrate with high percentages of sulphides and carbonaceous matter, which justify the need for oxidative pretreatment. Notwithstanding the above, even after the biooxidation pretreatment, the results of the BIOX $^{\circledR}$ CIL tailings indicated relatively higher gold deportments in the carbonaceous matter (about 50\%) and quartz, justifying the high tailings values generally reported for the BIOX ${ }^{\circledR}$ operations.

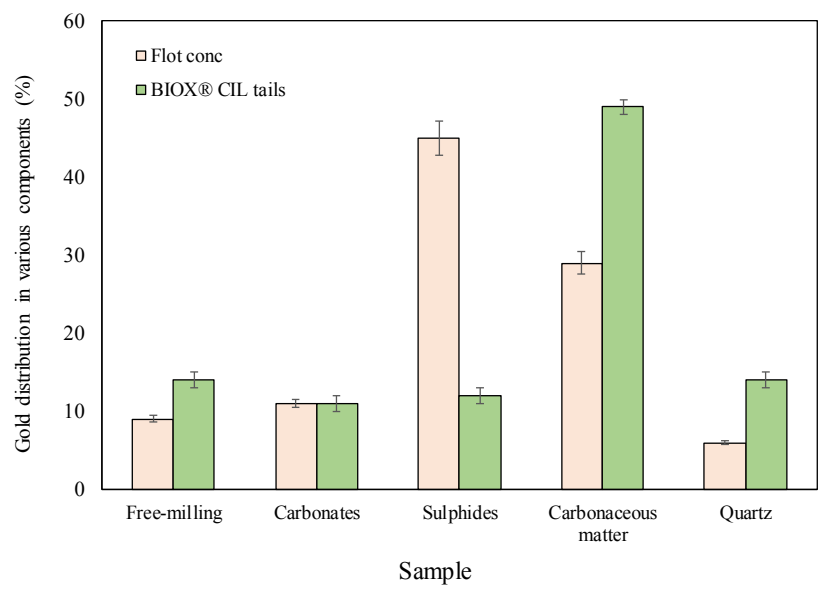

Figure 8. Gold deportment in flotation concentrate and BIOX ${ }^{\circledast}$ CIL Tails.

\section{Deductions from the Characterisation Study}

Excessive frothing in BIOX $^{\circledR}$ reactors may be caused by operational inefficiencies such as low BIOX $\mathrm{pH}$, poor bacterial activity (dead bacteria), high temperatures on the reactors, carry-over of flotation reagents and flooding of impellers [35]. However, persistent frothing may be due to minerals of high hydrophobicity in the ore. By comparing the mineralogical results of the ROM sample and the flotation concentrate, there was an increase in the concentration of the mica group of minerals from $2 \%$ to $18 \%$. Mica is hydrophobic and readily floats in either acidic or alkaline environments 
even with little or no conditioning [36]. This hydrophobic property of mica can cause flotation type froth in the biooxidation process, resulting in overflow of froth in BIOX $^{\circledR}$ reactors as shown in Figure 9. Frothing causes several nuisances on $\mathrm{BIOX}^{\circledR}$ such as overflow of acidic material outside of reactor bounded areas, corrosion of adjacent steel work and short circuiting of sulphide-carrying froth-bearing gold. Such carry-overs lead to gold losses in the counter current decantation (CCD) washing stage as the floating gold-carrying froth is collected in the effluent to tailings.

The froth may also create further challenges in the CIL circuit where a froth depth of over $1.0 \mathrm{~m}$ can be generated [37]. The froth depth does not mix with the bulk of the slurry resulting in short-circuiting of poorly leached material into the leach tailings.

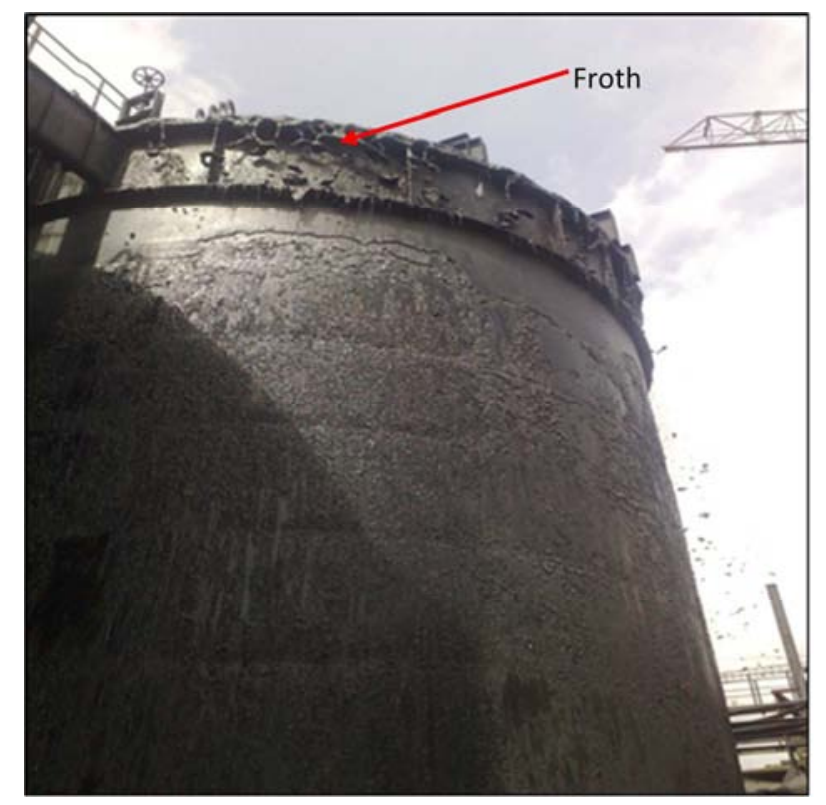

Figure 9. Froth overflowing from the continuously stirred tank reactors.

The ore utilised in this study had organic carbon concentration of $1.08 \%$, and this increased during flotation to $3.21 \%$ in the flotation circuit. In the BIOX $^{\circledR}$ CIL feed, the organic carbon content was a high of $6.67 \%$. These organic carbon percentages translated into preg-robbing indices of $64.4 \%$ and $72.7 \%$ for the flotation concentrate and BIOX $^{\circledR}$ CIL feed respectively. The presence of active preg-robbers implies the efficiency of CIL operations will depend on the amount of activated carbon utilised in competitive adsorption with carbonaceous matter [14].

Since the $\mathrm{BIOX}^{\circledR}$ CIL feed is a product of sulphide oxidation, incomplete oxidation generated partially-oxidised sulphides which acted as cyanicides [5], reducing the availability of oxygen and cyanide in the cyanidation circuit. This above led to increased reagent consumption during cyanidation, and partly accounted for the high post-CIL solid residues. Other causes of high gold in tailings may be attributed to the formation of jarosite $[17-18,27]$ that coats sulphides, and results in incomplete oxidation, and hence unliberated gold. Coatings on the gold surface as seen in
Figure 10 from related investigations [18] led to decreased access of the coated gold particles to lixiviants during the cyanidation process, resulting in high leach residues.

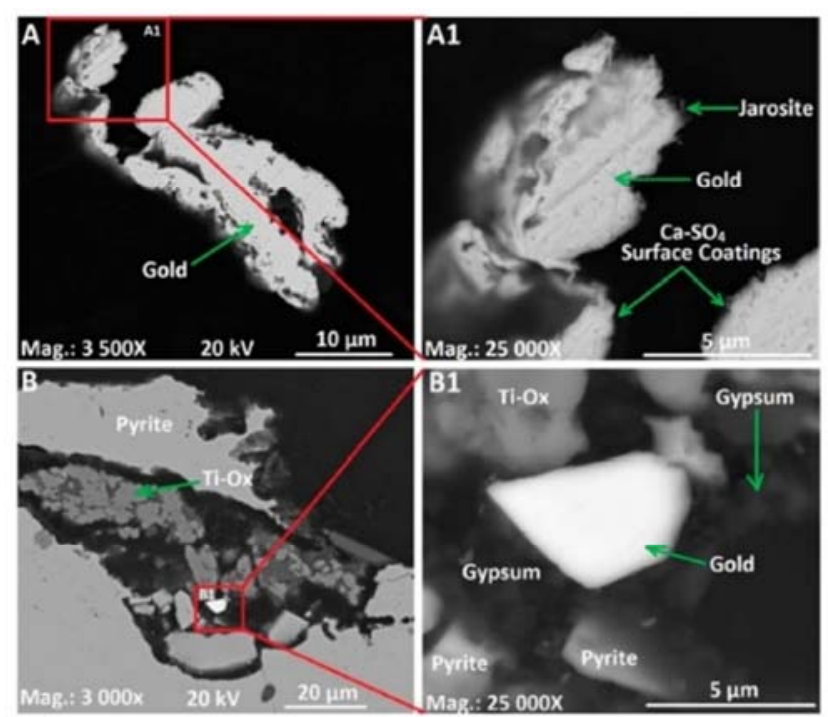

Figure 10. BSED photomicrographs showing gold particles with gypsum and jarosite surface coatings [18].

\section{Conclusions}

This paper investigated the courses of excessive continuous frothing, incomplete sulphide oxidation, high reagent consumption, high cyanidation residues and low overall recovery encountered in biooxidation of refractory ores. Characterisation of four sample streams of a biooxidation plant namely: run-of-mine ore (ROM), flotation concentrate (FC) which serves as biooxidation feed $\left(\mathrm{BIOX}^{\circledR}\right.$ Feed), biooxidised product $\left(\mathrm{BIOX}^{\circledR}\right.$ CIL Feed) and the cyanidation tailings $\left(\mathrm{BIOX}^{\mathbb{B}}\right.$ CIL Tails) revealed that the main minerals present comprised quartz, chlorites, plagioclase feldspar, dolomite, pyrite and mica group. Organic carbon was noted in all the investigated samples. From an initial 2\%, the concentration of mica increased to $18 \%$ in the flotation concentrate as identified in the QXRD analysis, pointing to the excessive frothing in the biooxidation circuit. QXRD identified the presence of gypsum and jarosite in the biooxidation product, and these secondary minerals passivated sulphide particles leading to incomplete oxidation. The presence of partially-oxidised sulphides and other cyanicides in the concentrate have the capacity to contribute to high reagent consumption during post-oxidation cyanidation, with attendant decrease in overall gold recovery. In addition, gypsum and jarosite encapsulated liberated gold particles as shown in the BSED analysis, an occurrence that reduced access to lixiviants in the subsequent cyanidation step, and returned high tailings values. The organic graphitic carbon identified through the BSED spectroscopy resulted in high preg-robbing indices. All the observations outlined above ultimately translated into high cyanidation tailings, an extension of which is low gold recoveries. 


\section{Acknowledgements}

The authors are grateful to Mr Mustapha Adam of the Future Industries Institute, University of South Australia, and $\mathrm{Mr}$ Michael Amon-Asiedu for assistance with the analytical work.

\section{References}

[1] P. Miller, and A. R. G. Brown, Bacterial oxidation of refractory gold concentrates, [in] Gold ore processing - project development and operations, Elsevier, Amsterdam, Netherlands, 2016, p. 359

[2] J. C. Yannopoulos, The Extractive Metallurgy of Gold, Von Nostrand Reinhold, New York, 1991.

[3] M. Aylmore and A. Jaffer, Evaluating process options for treating some refractory ores, Proceedings of Alta Gold Conference 2012, Perth, Australia, 2012.

[4] C. L. Brierley, Mining biotechnology: research to commercial development and beyond", In: Rawlings, D. E. (Ed.), Biomining: theory. microbes and industrial processes, Springer Verlag, Berlin, Germany, 1997, p. 3.

[5] J. Marsden, and I. House, The Chemistry of gold extraction, $2^{\text {nd }}$ edition, Ellis Horword, New York, 2006.

[6] G. J. Olson, J. A. Brierley and C. L. Brierley, Bioleaching review part B: progress in bioleaching: applications of microbial processes by the minerals industries, Appl. Microb. Biotechnol., 97 (2013) No. 17, p. 7543.

[7] H. R. Watling, Review of biohydrometallurgical metals extraction from polymetallic mineral resources. Miner., 5 (2015), p. 1.

[8] S. Hedrich, A. G. Guézennec, M. Charron, A. Schippers, and C. Joulian, Quantitative monitoring of microbial species during bioleaching of a copper concentrate, Frontiers in Microbiol., 7 (2016), p. 2044.

[9] D. E. Rawlings, Microbially-assisted dissolution of minerals and its use in the mining industry, Pure Appl. Chem., 76 (2004), No. 4 , p. 847

[10] R. K. Amankwah, W. T. Yen, and J. Ramsay, A two-stage bacterial pretreatment process for double refractory gold ores, Miner. Eng., 18 (2005), p. 103.

[11] J. A. Brierley, and C. F. Kulpa, Biometallurgical treatment of precious metal ores having refractory carbon content, US Patent, 5 (1993), p. 244.

[12] G. Ofori-Sarpong, and K. Osseo-Asare, Preg-robbing of gold from cyanide and non-cyanide complexes: effect of fungi pretreatment of carbonaceous matter", Int. J. Miner. Process, 119 (2013), p. 27.

[13] G. Ofori-Sarpong, K. Osseo-Asare, and M. Tien, "Mycohydrometallurgy: biotransformation of double refractory gold ores by the fungus, Phanerochaete chrysosporium", Hydrometallurgy, 137 (2013), p. 38.

[14] A. S. Adam, G. Ofori-Sarpong, and R. K. Amankwah, Assessing the challenges in the extraction of gold from bacterial-treated double-refractory concentrate", [in] Proceedings of the SME Annual Meeting, Feb. 19 - 22, 2017, Denver, CO, Preprint 17-014, p. 1.
[15] Anon, BIOX Comparative Data, Discussion Session Survey, Unpublished Report, BIOX Users Conference, Jinfeng, China, 2013.

[16] R. K. Asamoah, M. Zanin, R. K. Amankwah, W. Skinner, and J. Addai-Mensah, "Characterisation of Tectonic refractory gold ore", Australasian Chemical Engineering Conference, Perth, W. Australia, paper no. 1104, 2014.

[17] R. K. Asamoah, M. Zanin, J. Gascooke, W. Skinner and J. Addai-Mensah, Refractory gold ores and concentrates part 1: mineralogical and physico-chemical characteristics. Miner. Proc. and Ext. Metal. 2019a, p. 1.

[18] R. K. Asamoah, M. Zanin, W. Skinner and J. Addai-Mensah., Refractory gold ores and concentrates part 2: gold mineralisation and deportment in flotation concentrates and bio-oxidised products, Miner. Proc. and Ext. Metal. 2019a, p. 1 .

[19] L. Lorenzen and van J. S. J. Deventer, The identification of refractoriness in gold ores by the selective destruction of minerals, Miner. Eng., 6 (1993), p. 1013.

[20] V. M. Torres and R. S Costa, Characterization of gold ores and cip tailings using a diagnostic leaching technique, [in] Proceedings of XIX I. M. P. C. Precious metals processing and mineral waste and the environment, 4 (1995), Chapter 3, pp. 15 .

[21] R. P. Hackl, What to be aware of in cyanidation of Bio-oxidised products, Innovations in gold and silver recovery, Randol Gold Conference Phase IV, Sacremento, California, 1989.

[22] K. Osseo-Asare, T. Xue and V. S. T. Ciminelli, Solution chemistry of cyanide leaching systems, [in] Precious Metals: Min., Ext. and Proc., The Metallurgical Society of AIME, Warrendale, PA, (1984), p. 173.

[23] D. M. Hausen, and C. H. Bucknam, Study of preg robbing in the cyanidation of carbonaceous gold ores from Carlin, Nevada", [in] Proceedings of 2nd Int. Congress on Appl. Mineral., AIME, Warrendale, PA, (1985), p. 833.

[24] P. A. Schmitz, S. Duyvesteyn, W. P. Johnson, L. Enloe, and J. McMullen, "Adsorption of aurocyanide complexes onto carbonaceous matter from preg-robbing goldstrike ore, Hydrometallurgy, 61 (2001), p. 121.

[25] W. T. Yen, R. K. Amankwah and Y. Choi, "Microbial pre-treatment of double refractory gold ores", [in] Proceedings of the 6th Int. Symposium, Hydrometallurgy 2008, Phoenix, USA, SME, Littleton, CO, (2008), p. 506.

[26] M. Márquez, J. Gaspar, K. E. Bessler and G. Magela, Process mineralogy of bacterial oxidized gold ore in São Bento Mine (Brasil), Hydrometallurgy, 83 (2006), pp. 114.

[27] K. Sasaki, T. Sakimoto, M. Endo, and H. Konno, FE-SEM study of microbially formed jarosites by Acidithiobacillus ferrooxidans. Mater. Trans., 47 (2006), No. 4, p. 1155.

[28] F. Habashi, Textbook of Hydrometallurgy, $2^{\text {nd }}$ Edition, Metallurgie Extractive, Quebec, Canada, 1999.

[29] M. Fantauzzi, C. Licheri, D. Atzei, G. Loi, B. Elsener, G. Rossi, and A. Rossi, Arsenopyrite and pyrite bioleaching: evidence from XPS, XRD and ICP techniques, Analyt. and Bioanalyt. Chem., 401 (2011), pp. 2237. 
[30] F. M. Gagliardi and J. D. Cashion "Mössbauer analysis of BIOX treatment of ores at Wiluna gold mine", Hyperfine Interactions, Western Australia, 218 (2013), No. 1-3, p. 95.

[31] M. J. Kruger, The importance of $\mathrm{pH}$ control in the biooxidation process, [in] Proceedings of the colloquium bacterial oxidation for the recovery of metals, Johannesburg, South Africa, 2000, p. 1.

[32] D. E. Rawlings, Industrial practice and the biology of leaching of metals from ores, J. of Industrial Microbiol. Biotechnol., 20 (1998), p. 268.

[33] H. Deveci A. Akcil and I. Alp, Bioleaching of complex zinc sulphides using mesophilic and thermophilic bacteria: comparative importance of $\mathrm{pH}$ and iron, Hydrometallurgy, 73 (2004), p. 293.
[34] H. Tan, D. Feng, G. Lukey and J. Van Deventer, The behaviour of carbonaceous matter in cyanide leaching of gold, Hydrometallurgy, 78 (2005), p. 226.

[35] J. W. Olivier, BIOX ${ }^{\circledR}$ Overview, BIOX Users Conference, Almaty, Kazakhstan, 2011.

[36] R. Tippin, H. Bruce, L. Huiatt and D. Butts, Silicate mineral and potash flotation, Adv. in Flotation Technol., SME, Littleton, Colorado, 1999, p. 199.

[37] A. S. Adam, Bogoso BIOX® Plant: An update on performance, challenges and opportunities, BIOX Users Conference, Johannesburg, South Africa, 2009. 